いのは同傾向であるが焼入時の硬度や与えた歪のバラッ キのため必放しも含鉛の影製は明瞭には認められなか つた.

3) 応力時効（短時間クリープラプチャ試験）

Fig. 3, Fig.4 にBグループの常温から 000 C まこ の各温度で行なつた応力時効の結果走示。常温から $400 \mathrm{C}$ までの $308 \mathrm{hr}$ の応力時効では伸びは大差ないが 制り，硬度は含鉛によりわずかに低下している。 $600^{\circ} \mathrm{C} て ゙ の$ 短時間ラプチ十坛験では明らかに含鉛により 破断時間は短かくなり破断時の伸び，絞りは向上する。 クリープ現象は歪による硬化乞温度が高いための軟化 （結晶の回復と再結晶）の組み合せで後者が前者より大 きければクリーブ速さは增加する. $500^{\circ} \mathrm{C}$, C での 含鉛によ々破断時間の減少や伸ざ, 较りの向上は再結晶 が無鉛のものより促進されるためこ考えられる。前報す の昇温引張試験で認められた 550 C での含鉛によっ延 生の回復向上もこれを裹付けるものであろう。

4) 結晶粒度

Table 3 に含鉛, 無鉛各試料の025 C 1200ㄷの 浸炭による $\gamma$ 粒度，コア一部の $\alpha$ 粒度， $900^{\circ} \mathrm{C}$ 焼準によ る $\alpha$ 粒度を示学.

$\gamma$ 粒り成長を阻止する析出物のうち AlN はこの效果 が大りが池ら6)は $\mathrm{Al}^{\circ}$ 。の少ない場台は鎙中 $\mathrm{SiO}_{2}$ の析出が多くりこ机 AlNより高温で安定なため

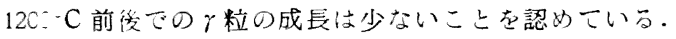
$\mathrm{Al}^{\circ}$ 。の少ないH, B グループはえの傾向にあるが, 含 鉛材はやや紐粒である。同しく $\mathrm{A} 1 \%$ の少ないLグルー フの含鉛 $\mathrm{L}_{\mathrm{F}}$ が無鉛 $\mathrm{L}_{2}$ より $\gamma$ 粒の成長が相当少ないの は鉛粒もこの成長阻止にあゔかつているここを示す。 $\mathrm{Al} \%$ の多い A, Cグループで汶 1200 - C での粗粒化か 甚しい.こ机は析出 $\mathrm{AlN}$ が多く $1200^{\circ} \mathrm{C}$ でまだ固溶し つつある7)こと示すが含鉛 $\mathrm{A}_{3}, \mathrm{C}_{2}$ は無鉛 $\mathrm{A}_{1}, \mathrm{C}_{1}$ よ り成長が少なく鉛の成長阻止作用によるもの上考えられ る.

$\alpha$ 粒度は変態の際の冷却望度, $\mathrm{A} 1 \mathrm{~N}$ その他微細な非 金属介在物今どの析出, 分布状態左右されると考えら れるが H C グループのように不純物, 非金属介在物の 少ない場合は微粒鉛が $\gamma \rightarrow \alpha$ 変態の際の $\alpha$ 粒の細粒化に 対しより効果的に㗢くものと考えられる. A， B グル一 ナは不純物, 介在物が多いため鉛粒の効果が目立たず必 らずしも合鉛による $\alpha$ 粒の湅粒化は珰められない。

\section{IV. 総}

\section{括}

1) 低炭素鋼の焼入時効では含鉛の影響は明らかてな く焼入時钓姼の歪時効硬化は含鉛によりやや楥和される 傾向にあるが焼隼材加工後の歪時効程明瞭ではない．

2) 低炭素鋼の応力時効では含鉛により常温より青熱 脆性域では硬度, 校りが低下し $500^{\circ} \mathrm{C}, 600^{\circ} \mathrm{C}$ では破 断時間诚少, 延性増加がうられ再結晶の促進が認められ る.

3 ）鉛は低炭素䤡の $900^{\circ} \mathrm{C} \sim 1200^{\circ} \mathrm{C}$ での粒の成長 を阻止するようであり $\alpha$ 粒についてもどちらかといえば 紐粒化の傾向にあるが $\gamma$ 粒程明瞭でない。

\section{交献}

1）小柳，荒木，松幔：鉄と鎙，49（1963）10， p. 1481

2) A. P. Weaver: Trans. Amer. Soc. Metals,
49 (1957), p. 497

3) 浅田, 他: 電気製鐝，31（1960）2，p. 74

4) A. H. Cottrell, 他: J. Iron \& steel Inst. (U. K.), 172 (1952), p. 301

5 ) 小柳, 荒木：鉄と鎡，50 (1964) 4, p. 689

6) 小池, 外：鉄々鎆, 42 (1956) 3, p. 244

7 ) IV. C. Leslie, 他: Trans. Amer. Soc. Metals, 46 (1954), p. 1470

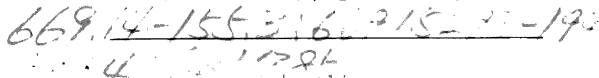

(168) 含 $\mathrm{Nb}$ 迅速窒化鋼の機械的性質 および熱処理特性について

(讯速空化鋼の研究一I )

特殊製鋼，技術部， No.64300

工博 日下邦男・荒术昭太郎・华尔木博

On the Mechanical Properties and Heat-treating Behavior of Niobiumbearing Rapid Nitriding Steel.

(Study of rapid nitriding steel-I)

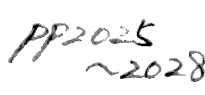

Kunio KUSAKa, Shotaro Arakt and Hiroshi SASAKI.

\section{I. 緒}

\section{言}

JIS SACM1 鎆なと通常の窒化鉂は，窒化処理時間か $50 \sim 100 \mathrm{hr}$ ときわめて長いのが欠点である。これにた いし, $\mathrm{Ti}$ 約 $2.5 \%$ 含有する鋼は，坌化温度を約 $05 . \mathrm{C}$ に高めることによつて窒化処理時間を $10 \mathrm{hr}$ 程度に短 縮することが可能である.11〜3ししししの鋼種は高 $\mathrm{Ti}$ 成分のため真空溶解法によつて溶製しなければならない 欠点がある。

ここでわれわれは，Ti 以外の各種合金元素を含有し た鋼について迅速窒化性を調べ, この結果迅速窒化性と は通常使用される窒化温度で速く，したがつて深く窒化 されることではなくて，窒化温度を上げて窒化した場合 に，十分高い表面硬度が得られることであるということ を知り，さらに週期率表で $\mathrm{Ia}, \mathrm{Va}, \mathrm{Va}$ 族に属する $\mathrm{V}$, $\mathrm{W}, \mathrm{Ta}, \mathrm{Zr}, \mathrm{Nb}, \mathrm{Cr}, \mathrm{Ti}$ 多多量に含有する鋼の間の 相対的な迅速窒化性の強さに規則的な関係のあることを 明らかにしだ).

われわれはこれら元素を多量に含有した鋼の実用化に ついて種々研究を行なつているが，今回は Nbを多量に 含有した鎆の機械的性筫抢よご熱処理特性などについて 調べた結果を報告する。

\section{II. 試料および実験方法}

まず，3 $\mathrm{KW}$ 高周波誘導哣により， $\mathrm{Nb}$ この他合金元 委量を変化させた $600 \mathrm{~g}$ 鎆塊を多数溶製し, これを角 $15 \mathrm{~mm}$ に䤨伸し，これより小試片を採取して，窒化特 性扰よび熱処理特性に扣よぼす合金成分の影曏を調べ た。

つぎに, 真空誘導炉によつて Table 1 に示方化学成

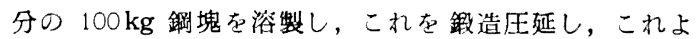
り各種機械試駼, 熱処理特性わよび窒化特性調查用試片 を作成した。

\section{III. 実 験 結 果}

1. 窒化硬度に戈よばす合金元素の影軠

Fig. 1 亿 $0.2 \% \mathrm{C}$ 鎆, $0 \cdot 9 \sim 6 \cdot 20,0 \mathrm{Nb}$ 鋼を $700^{\circ} \mathrm{C} \times$ 
Table 1. Chemical composition of steels tested.

\begin{tabular}{|c|c|c|c|c|c|c|c|c|c|c|c|c|c|}
\hline \multirow{2}{*}{$\begin{array}{c}\text { Steel } \\
\text { No. }\end{array}$} & \multirow{2}{*}{ Type of steel } & \multicolumn{12}{|c|}{ Chemical composition $(\%)$} \\
\hline & & $\mathrm{C}$ & $\mathrm{Si}$ & $\mathrm{Mn}$ & $\mathrm{P}$ & $\mathrm{S}$ & $\mathrm{Ni}$ & $\mathrm{Cr}$ & Mo & $\mathrm{V}$ & $\mathrm{Cu}$ & $\mathrm{Al}$ & $\mathrm{Nb}$ \\
\hline $\begin{array}{l}\text { C } 45 \\
\text { C } 46 \\
\text { C } 47\end{array}$ & $\begin{array}{l}5 \mathrm{Nb}-1 \mathrm{~V}-0 \cdot 1 \mathrm{Al} \\
5 \mathrm{Nb}-1 \mathrm{~V}-1 \cdot \mathrm{OA} 1 \\
5 \mathrm{Nb}-0 \cdot 1 \mathrm{Al}\end{array}$ & $\begin{array}{l}0.25 \\
0.20 \\
0.26\end{array}$ & $\begin{array}{l}0 \cdot 13 \\
0 \cdot 23 \\
0 \cdot 12\end{array}$ & $\begin{array}{l}0.73 \\
0.9 \\
0.70\end{array}$ & $\begin{array}{l}0 \cdot 008 \\
0 \cdot 005 \\
0 \cdot 005\end{array}$ & $\begin{array}{l}0.012 \\
0 \cdot 013 \\
0.012\end{array}$ & $\begin{array}{l}3 \cdot 42 \\
3 \cdot 42 \\
3 \cdot 49\end{array}$ & $\begin{array}{l}1 \cdot 18 \\
1 \cdot 19 \\
1 \cdot 21\end{array}$ & $\begin{array}{l}0.25 \\
0.25 \\
0.24\end{array}$ & $\begin{array}{c}0.97 \\
0.98 \\
-\end{array}$ & $\begin{array}{l}0.04 \\
0.02 \\
0.02\end{array}$ & $\begin{array}{l}0.10 \\
0.73 \\
0.14\end{array}$ & $\begin{array}{l}5 \cdot 03 \\
5 \cdot 15 \\
5 \cdot 07\end{array}$ \\
\hline
\end{tabular}

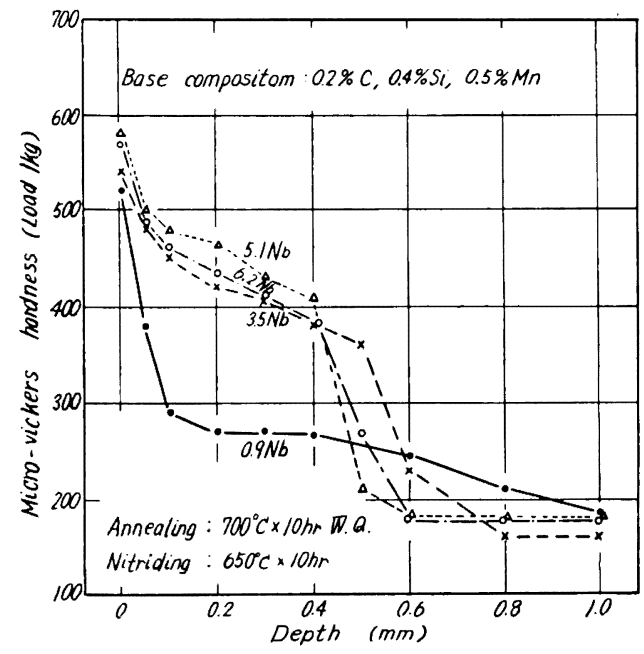

Fig. 1. Effect of $\mathrm{Nb}$ content on hardness distribution curves of nitrided case.

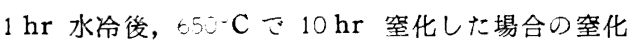
硬化曲線を示す。これより含 $\mathrm{Nb}$ 鋼には窒化により 硬化する性質があるが，Nbのみでは $6 \%$ 以下の 含有量で十分高い窒化硬度は得られないことがわか る。

次に Nbのこでは窒化硬度が低いのて，この点を 補うために，50。Nb 䤡にVを $1 \%$ 添加したものに ついて窒化硬度をしらべた。その結果窒化時間 10 $\mathrm{hr}$ の場合, 窒化温度 $600^{\circ} \mathrm{C}$ では $\mathrm{H}_{\mathrm{M}} \mathrm{V} 1200$, $650^{\circ} \mathrm{C}$ では $\mathrm{H}_{\mathrm{M}} \mathrm{V} 650,700^{\circ} \mathrm{C}$ では $\mathrm{H}_{\mathrm{M}} \mathrm{V} 850$ を 得ることができた。

\section{2. 窒化特性}

Fig. 2 は武料 C 45, C 46, C 47 について, 窒化 温度，時間をかえて，等化深さを測定した結果であ ろ.いずれの鋼種るほぼ同様の窒化特性を有し, 例 えば窒化温度 6.50 C Cは窒化深さ $0.4 \mathrm{~mm}$ を得る には，窒化時間は $10 \mathrm{hr}$ 程度あればよいととがわ

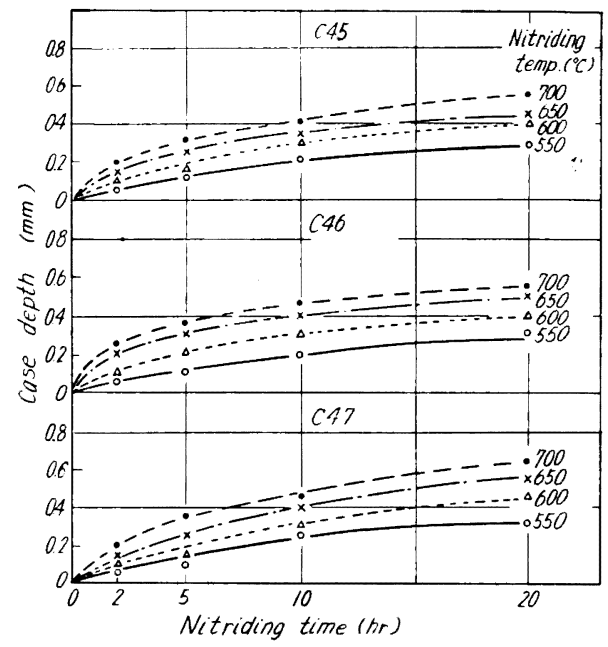

Fig. 2. Effect of nitriding temperature and time on case depth.

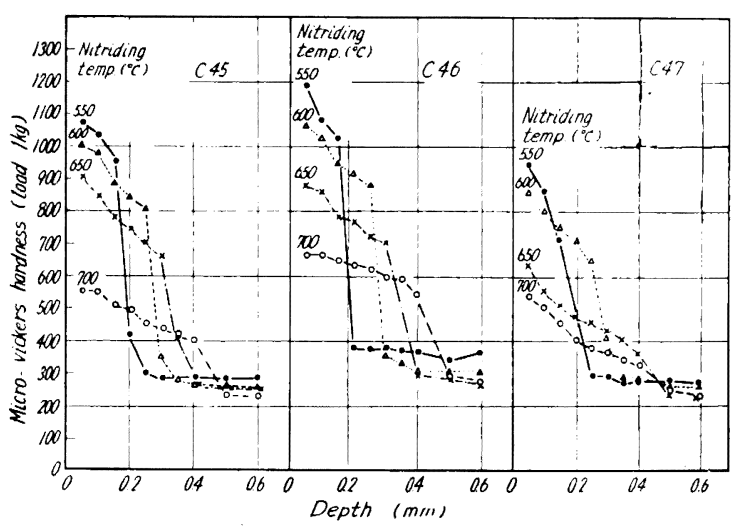

Fig. 3. Hardness distribution curves of nitrided case. (nitriding time: $10 \mathrm{hr}$ )

Table 2. Relation between required case hardness and core hardness etc.

\begin{tabular}{|c|c|c|c|}
\hline $\begin{array}{l}\text { Required case hardness } \\
\left(\mathrm{H}_{\mathrm{M}} \mathrm{V}\right)\end{array}$ & Steel No. & Nitriding temp. and time & $\begin{array}{l}\text { Core hardness } \\
\text { and impact strength }\end{array}$ \\
\hline $850 \mathrm{~min}$ & $\begin{array}{l}\text { C } 45 \\
\text { C } 46 \\
\text { C } 47\end{array}$ & $\begin{array}{l}600 \sim 650^{\circ} \mathrm{C} \times 10 \mathrm{hr} \\
1 / " \\
600^{\circ} \mathrm{C} \times 10 \mathrm{hr}\end{array}$ & $\begin{array}{lr}\operatorname{Rc} 20 \sim 18,3 \cdot 5 \sim 4.5 \mathrm{~kg}-\mathrm{m} / \mathrm{cm}^{2} \\
\operatorname{Rc} 26 \sim 21,2 \cdot 5 \sim 3.5 \mathrm{~kg}-\mathrm{m} / \mathrm{cm}^{2} \\
\operatorname{Rc} 18, & 4.5 \mathrm{~kg}-\mathrm{m} / \mathrm{cm}^{2}\end{array}$ \\
\hline $950 \mathrm{~min}$ & $\begin{array}{l}\text { C } 45 \\
\text { C } 46 \\
\text { C } 47\end{array}$ & $\begin{array}{c}600^{\circ} \mathrm{C} \times 10 \mathrm{hr} \\
11 \\
-\end{array}$ & $\begin{aligned} & 3 \cdot 5 \mathrm{~kg}-\mathrm{m} / \mathrm{cm}^{2} \\
& 2.5 \mathrm{~kg}-\mathrm{m} / \mathrm{cm}^{2} \\
&-\end{aligned}$ \\
\hline
\end{tabular}


Table 3. Mechanical properties after water cooling from $800^{\circ} \mathrm{C}$.

\begin{tabular}{c|c|c|c|c|c|c}
\hline \hline \multirow{2}{*}{ Steel No. } & \multicolumn{5}{|c}{ Mechanical properties } \\
\cline { 2 - 7 } & $\begin{array}{c}\text { Yield point } \\
\left(\mathrm{kg} / \mathrm{mm}^{2}\right)\end{array}$ & $\begin{array}{c}\text { Tensile } \\
\text { strength } \\
\left(\mathrm{kg} / \mathrm{mm}^{2}\right)\end{array}$ & $\begin{array}{c}\text { Elongation } \\
(\%)\end{array}$ & $\begin{array}{c}\text { Reduction } \\
\text { of area } \\
(\% / 0)\end{array}$ & $\begin{array}{c}\text { Impact } \\
\text { strength } \\
\left(\mathrm{kg}-\mathrm{m}^{\prime} / \mathrm{cm}^{2}\right)\end{array}$ & $\begin{array}{c}\text { Brinell } \\
\text { hardness } \\
\left(\mathrm{H}_{\mathrm{B}}\right)\end{array}$ \\
\hline C45 & $69 \cdot 5$ & $77 \cdot 3$ & $21 \cdot 0$ & $45 \cdot 8$ & $4 \cdot 1$ & 231 \\
C46 & $70 \cdot 2$ & $76 \cdot 0$ & $22 \cdot 5$ & $46 \cdot 4$ & $4 \cdot 1$ & 241 \\
C47 & $65 \cdot 6$ & $74 \cdot 4$ & $21 \cdot 2$ & $43 \cdot 7$ & $5 \cdot 2$ & 224 \\
\hline
\end{tabular}

かる。

次に Fig. 3 は各鋼種を $550 \sim 702^{\circ} \mathrm{C}$ の各温度 て窒化した場合の窒化硬化曲線を示したものであ ๖. V を含有しないC 47 が最も硬度低!，1\% V 含有し，さらに Al を $1 \%$ 含有宁るC 46 が最 も硬度高く，1\% V を含有し $\mathrm{Al}$ 量の低い $\mathrm{C} 45$ 法この中間の硬度を示す。実用的にはかりに窒 化深さは $0.4 \mathrm{~mm}$ 以上, 表面硬度は $\mathrm{H}_{\mathrm{M}} \mathrm{V} 850$ 以上を必要とするとすれば， $10 \mathrm{hr}$ 窒化では， $\mathrm{C} 45$ および C 46 では窒化温度は $600 \sim 650^{\circ} \mathrm{C}$, $\mathrm{C} 47$ は $600^{\circ} \mathrm{C}$ になる。 また $\mathrm{H}_{\mathrm{M}} \mathrm{V} 950$ 以上を 必要とすれば，C 45，46 は窒化温度は。 方，C47 は該当する温度がない。

. 時効硬化特性

内部強度の点から，被料には3000 Ni 打よご $1 \%$ または $0.1 \% \mathrm{Al}$ を含有させて時効硬化性を

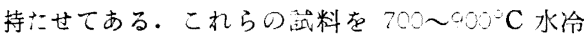
後, 450〜 650 C 河各温度て 1 10 hr 時効させ て硬度わよび衝撃值の変化をしらべた。.Fig. 4 は $900^{\circ} \mathrm{C}$ 水冷の場合を示したものだ，C45 拉よで C46は450〜

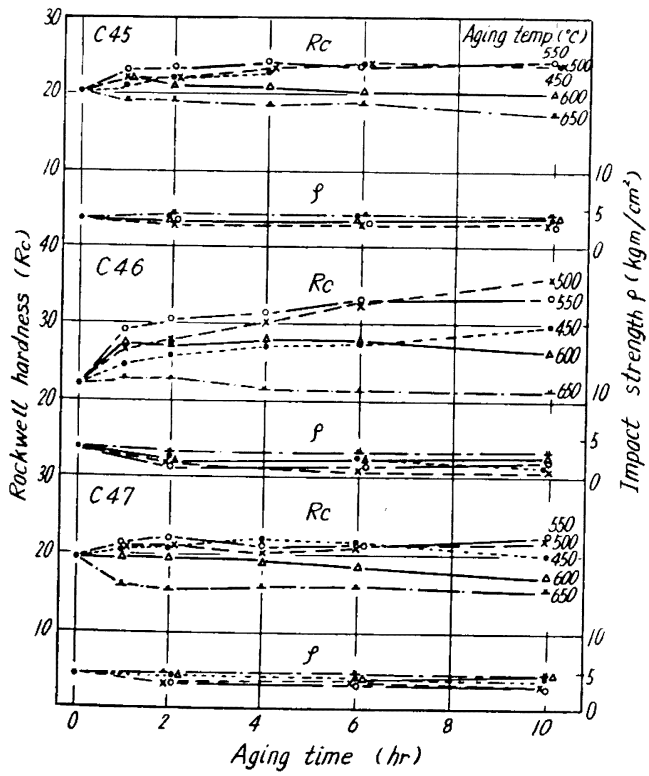

Fig. 4. Effect of aging temperature and time on hardness and charpy impact strength. (Annealing: $900^{\circ} \mathrm{C}$ watercooling)

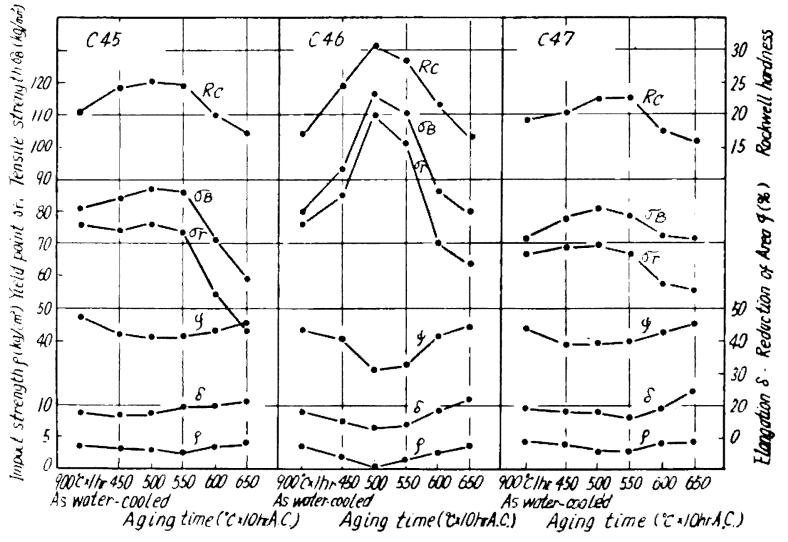

Fig. 5. Effect of aging temperature on mechanical properties.

$600^{\circ} \mathrm{C}, \mathrm{C} 47$ は 450 550 C の各温度で時効硬化が認め られる。こして C 45 およで C 47 の時効硬化はわ加 ごるが，C46の時効硬化はいちじるしく，500-C× $10 \mathrm{hr}$ 時効では Rc 22 から Rc 55.5 亿まで硬度が上 昇する.また衝撃值は硬度の変化と逆の傾向を示し, $10 \mathrm{hr}$ 時効後は $\mathrm{C} 45$ は $2 \cdot 5 \sim 4.5 \mathrm{~kg}-\mathrm{m} / \mathrm{cm}^{2}, \mathrm{C}+7$ は $3 \cdot 0 \sim 4 \cdot 5 \mathrm{~kg}-\mathrm{m} / \mathrm{cm}^{2}$ になる. C46 は時効によっ硬度の 変化がいちじるしいので, 衙撃值の変化もいちじるし く、たとえば $650^{\circ} \mathrm{C}$ 時効では $3.5 \mathrm{~kg}-\mathrm{m} / \mathrm{cm}^{2}$ であるの にたいし， $500^{\circ} \mathrm{C}$ 時効では $0 \cdot 5 \mathrm{~kg}-\mathrm{m} / \mathrm{cm}^{2}$ になる。

な扣前項化記した実用上の要求を適用する上，この場 合の硬度打よご衝慗值は Table 2 のようにふる。

4. 機械的性筫

各鋼種を $700 \sim 1100^{\circ} \mathrm{C}$ の各温度から水冷して機栈的 性質を調べた。この絬果 300 C 以下の温度では, 温度の 上昇とともに硬度, 抗張力打よで降伏点は減少し, 伸

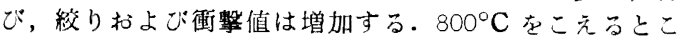
んどは逆に硬度などは增加し，伸びなどは減少すっ。

Table 3 亿例乞して $000 \mathrm{C}$ 水冷の場合の機械的性貿せ 示す.

次に Fig. 5 は $\mathrm{C}$ 水冷後, 450 550 C の各温度 て $10 \mathrm{hr}$ 時効処理した場合の機械的性質を示したもの である.いずれの鋼種も約 $500^{\circ} \mathrm{C}$ でもともいちじる しく時効硬化し, 硬度, 抗張力扰よび降伏点は最高にな り，伸心゙，校り扔よび衝撃值は最低になるが，天の変化 は C46 がもつともいちじるしい.

$$
\text { IV. 結 䨪 }
$$

以上含 $\mathrm{Nb}$ 迅速窒化鋼の窒化特性，熱処理特性および 
機械的性質について試験した結果を報告したが，こ机よ り $5 \% \mathrm{Nb}, 1 \% \mathrm{~V}$ を含有したものは, 窒温度を $600^{\circ} \mathrm{C}$ 上 するこしによつて窒化時間を $10 \mathrm{hr}$ に短縮でき，この 時窒化硬度 $\mathrm{H}_{\mathrm{M}} \mathrm{V} 950$ 以上が得られ，機珹的性質も良好 ごるこしがわかつた。

\section{文献}

1) 矢島, 古沢：日本金属学会誌，26 (1962), p. 141

2 ) 矢島, 古沢: 日本金属学会誌, 26 (1062), p. 371

3 ) 矢島, 日下, 鶴見, 山崎：鉄上銅，49 (1963), p. 550

4 ）日下, 荒木, 佐々木: 日本金属学会, 昭 38 秋季 大会講演概要, p. 62

(169)

\section{$\mathrm{Cr}$ 鋼の焼戻過程における降伏 現象の異常性}

（鋼の焼戻過程に去ける降伏現象の異常性に 関吉万研究一I）

日本製鋼所，室蘭製作所

No.6433/

工博 石塚 宽・○干葉隆一・大西敬三

Abnormality in Yield Property of $\mathrm{Cr}-$ Steels during Tempering. PP2028 2030. (Studies on abnormality in yield property of steels during tempering-I)

Dr. Hiroshi Ishizuka, Ryuichi Снiва and Keizo Onishi.

\section{I. 緒言}

$\mathrm{Cr}$ 鋼の焼戻しに関する研究は古くから行なわれてい るが，K.J. IRriNe ら ${ }^{1)} 12 \% \mathrm{Cr}$ 鋼の $550 \mathrm{C}$ の焼 戻しにおいて降伏比が異常低下する現象を钼察してい る.筆者らもマルテンサイト采 $13 \% \mathrm{Cr}$ 鋼の熱処理試験 においこ，これと全く同様の現象を観察した。しかしこ の問題についてはまだ詳細に研究されていないままたこ の現象は蒸気タービン翼材などの高 $\mathrm{Cr}$ 鋼にとつて重要 な問題であると考えられる。そこでその本質を明らかに するために一連の研究を実施中である．本報ではまず数 種の $\mathrm{Cr}$ 鋼の焼戻過程に扔ける降伏比の異常低下現象に ついて試験した結果を報告する。

\section{II. 試料および試験方法}

この試験に用いた材料の化学組成は Table 1 亿示す 通りで，いずれも低 C.Cr 鋼である。このうち $2 \%$ ， $4 \%$ および $8 \% \mathrm{Cr}$ 鋼の試料は $50 \mathrm{~kg}$ 鋼塊から, $13 \% \mathrm{Cr}$

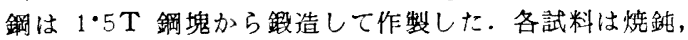
焼入却後，000 700 C 間種々の温度で焼庆しを行ない，

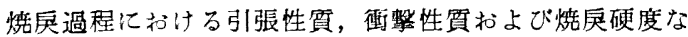
どの変化を観察した。な打引張試験は $14 \mathrm{~mm} \oint$ 引張試

Table 1. Chemical composition of steels tested.

\begin{tabular}{r|c|c|c|c|c|c|c|c|c}
\hline \hline Steel & C & Si & Mn & P & S & Ni & Cr & Cu & Mo \\
\hline $2 \%$ Cr & $0 \cdot 16$ & $0 \cdot 22$ & $0 \cdot 42$ & $0 \cdot 015$ & $0 \cdot 012$ & $0 \cdot 19$ & $1 \cdot 87$ & $0 \cdot 20$ & $0 \cdot 06$ \\
$4 \% \mathrm{Cr}$ & $0 \cdot 23$ & $0 \cdot 24$ & $0 \cdot 34$ & $0 \cdot 019$ & $0 \cdot 015$ & $0 \cdot 20$ & $4 \cdot 30$ & $0 \cdot 20$ & $0 \cdot 07$ \\
$8 \% \mathbf{C r}$ & $0 \cdot 16$ & $0 \cdot 28$ & $0 \cdot 44$ & $0 \cdot 016$ & $0 \cdot 014$ & $0 \cdot 20$ & $7 \cdot 93$ & $0 \cdot 19$ & $0 \cdot 05$ \\
$13 \% \mathrm{Cr}$ & $0 \cdot 13$ & $0 \cdot 26$ & $0 \cdot 50$ & $0 \cdot 018$ & $0 \cdot 008$ & $0 \cdot 20$ & $12 \cdot 80$ & $0 \cdot 13$ & $0 \cdot 05$ \\
\hline
\end{tabular}

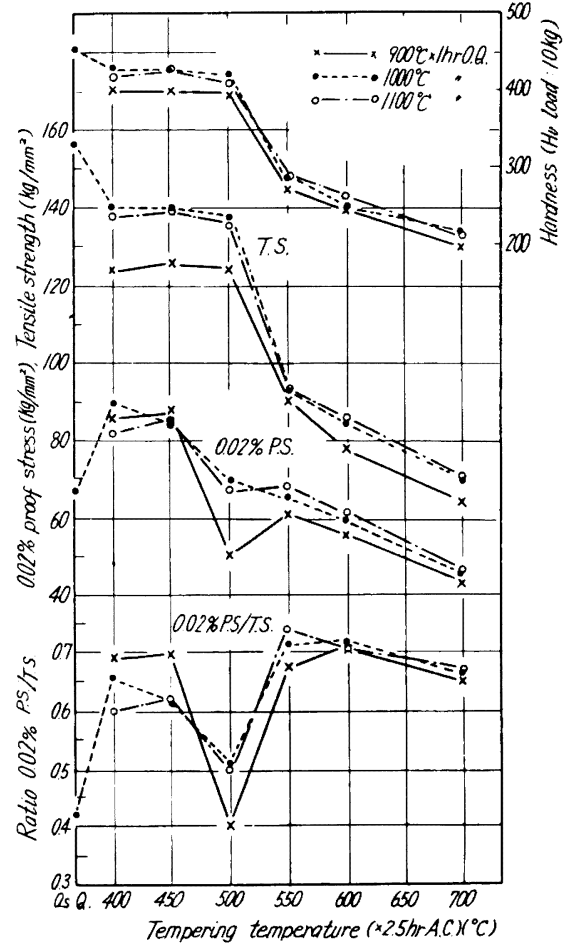

Fig. 1. Effect of hardening temperature on the mechanical properties of tempered $13 \% \mathrm{Cr}$-steel.

験片を用い，主として $1 \mathrm{~mm} / \mathrm{min}$ の歪速度の下で行な つた.また耐力としては $0.02 \%$ の永久伸でを示す点を 採用した.

\section{III. 試 験 結 果}

1. $13 \% \mathrm{Cr}$ 鎆についての試験結果

(1) 烧入温度の影響

Fig. 1 は, 000,1000 および $1100^{\circ} \mathrm{C}$ の温度に $1 \mathrm{hr}$ 加熱後烧入れした低 C・13\% Cr 鋼の焼戻過程に扣ける 硬度および引張り性質の変化を示したものである.高 $\mathrm{Cr}$ 鋼は焼戻温度 450 〜 $500^{\circ} \mathrm{C}$ に扣いてわずかに第2 次硬化 の現象をあらわし, $500^{\circ} \mathrm{C}$ 以上の高温度範囲での焼戻し では急激に軟化するが，引張り強さも硬度と全く同様の 経過をたどる. 一方 0.02\% 耐力は, 引張り強さと同し 傾向を示さず，第 2 次硬化が扣こる段階では低下する。 したがつて 0.02\%降状比は，図に明らかなように，500 ${ }^{\circ} \mathrm{C}$ 付近们いて急激に低下する. 次に第 2 次硬化を過 ぎ, over-ageing により軟化がおこる段階では降伏比 は再び增大し, 焼戻温度 $600^{\circ} \mathrm{C}$ 付近で最高值を示す。

以上のように $13 \% \mathrm{Cr}$ 鋼において, 降伏比は第2 次硬 化を示す段階で急激に低下することが観察されたが，こ の現象は興味ある事実であ万う.なお Fig. 1 亿おいて, 耐力扰よび降伏比の異常低下現象は, 焅入温度が $900^{\circ} \mathrm{C}$ の場合において特に顕著にあらわれた。

（2）烧入加熱保持時間の影掣

焼入温度 $1000^{\circ} \mathrm{C}$ の場合について, その加熱保持時間 


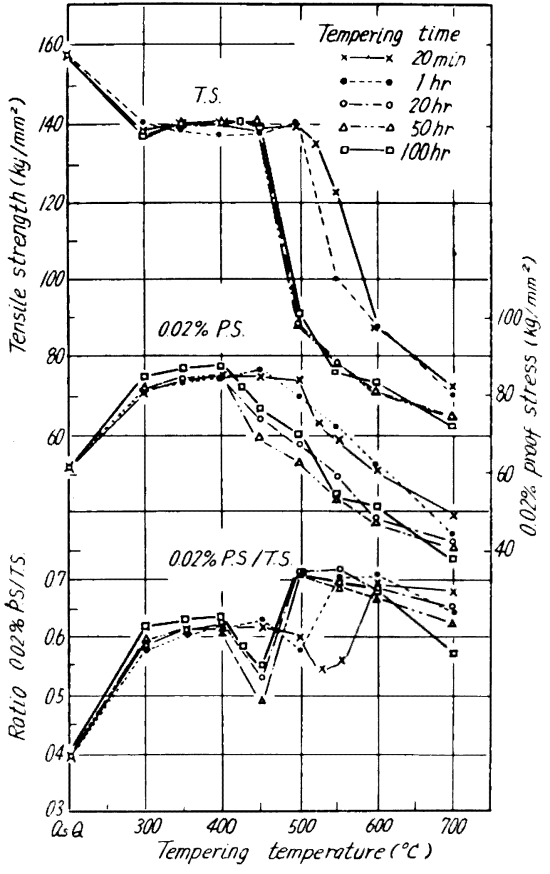

Fig. 2. Effect of tempering time on the tensile property of tempered various $\mathrm{Cr}$-steels hardened at $1050^{\circ} \mathrm{C}$.

を2 $\mathrm{min}, 1 \mathrm{hr}$ 扰よ゙ $2 \mathrm{hr} の 3$ 種類に変化せしめて 焼入れを行ない，のち狫戻しを行なつて，降伏比の異常 低下現象におよぼす焼入保持時間の影響，す心わちオ一 ステナイトへの炭化物固溶度の影響を調べ汒。三の結 果, 降伏比の異常低下は, 焼入時の加熱保持時間の影響 をあまりうけることなく，同様にあらわ机るここを知つ た.

\section{（3）焼戻保持時間の影算:}

降伏比の異常低下現象に対省る烧戻保持時間の影響を みるために, $1050^{\circ} \mathrm{C} よ り$ 焼入れした試料について焼戻 保持時間を $20 \mathrm{~min}, 1 \mathrm{hr}, 20 \mathrm{hr}, 50 \mathrm{hr}$ および $100 \mathrm{hr}$ の 5 通りに変えて試験を行なつた。その結果泣 Fig. 2 に示す通りである。すなわち，烧送保持時間が長くなる につれて第 2 次硬化を示す焼戻温度はやや低温側に移動 するが，引張り強さ扣よびの $00 \%$ 耐力の変化もこれと 全く対忍し，したがつて降伏比の異常低下を示す温度も 焼戻保持時間が長い場合には低温側に移動する。この結 果から, 降伏比の異常低下の現象は第 2 次硬化の現象々 よく対応することがわかる。な打同図に扎いた，焼戻時 間の影響は $20 \mathrm{hr}$ まではその影镂があらわれるが，二れ 以上長時間の焼戻しでは硬度扰よび引張性質に変化はみ られない。

\section{（4）焼戻冷却速度の影犁}

降伏比の異常低下現象に対する烧戻脆性の影望をみる ために，焼戻終了後水中で急冷した場合と炉中冷却 $(0.5$ ${ }^{\circ} \mathrm{C} / \mathrm{min}$ 以下) した埸合の両者について引張性質を比較 した。その結果いずれの場合にも，焼戻温度 $500 \mathrm{C}$ 附

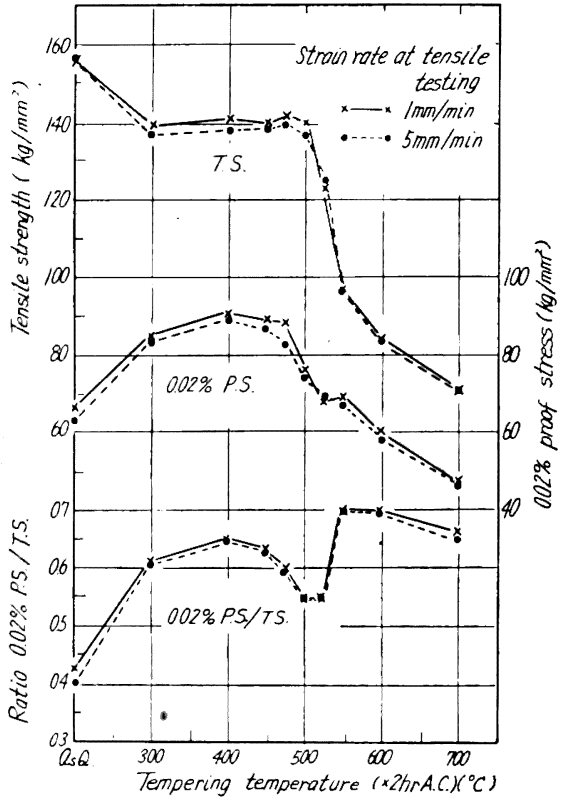

Fig. 3. Effect of strain rate at tensile testing on the tempered $130.0 \mathrm{Cr}$-steel hardened at $\log \mathrm{C}$.

近に降伏比の異常低下がほぼ同程度におこり, 焼戻時の 冷却速度の影製は特にみら机なかつた。

\section{（5）引張り歪速度の影響}

以上の武験に打いては, 引張り歪速度をいずれも 1 $\mathrm{mm} / \mathrm{min}$ こして引張試験を行なつたが, 降伏比の異常 低下現象に対して引張速度はどのような影響を与えるか についてさらに検討を加えた．Fig. 3 は引張り速度を $1 \mathrm{~mm} / \mathrm{min}$ 扰よび $5 \mathrm{~mm} / \mathrm{min}$ の場合における結果を 比較して示したものである。ただし焼入温度は $1000^{\circ} \mathrm{C}$, 焼戻時間は $2 \mathrm{hr}$ である。すなわちこの結果からこの 程度の引張り歪速度の筑囲内では, 引張り強さ，0・02\%

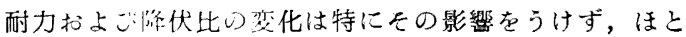
んと゚変らないこょが分つた。

\section{2. 各種 $\mathrm{Cr}$ 鍸についての試験結果}

以上は $130.0 \mathrm{Cr}$ 鋼について，この焼戻過程において降 伏比の異常低下現象の打こるここを観察したが，この現 象は 130 。Cr 鋼に限つておこるものてあるかどうかをみ るために，Table 1 に示したように2\%，4\% 扰よび $8 \% \mathrm{Cr}$ 鋼を溶製し，これら各 $\mathrm{Cr}$ 鎆の焼戻過程に打ける 引張性質の変化を調べた．Fig. 4 に $13 \% \mathrm{Cr}$ 鋼の場合 を含めてこの試験結果を示吉。ただし試料の焼入れは， 2〜 $3 \% \mathrm{Cr}$ 鋼については $00 \mathrm{C} \times 1 \mathrm{hr} \mathrm{O} . \mathrm{Q} ., 13 \% \mathrm{Cr}$ 鋼 は $1000^{\circ} \mathrm{C} \times 1 \mathrm{hr} \mathrm{O} . \mathrm{Q}$. とし, 焼戻保持時間はいず机も $2 \mathrm{hr}$ である. $\mathrm{Cr}$ 銅においては $\mathrm{Cr}$ 含有量の增加に伴つ て烍厌軟化の遅滞がうり，約 $8 \%$ 以上に打いて第 2 次 硬化の現象をあらわす。引張り強さの変化もこれとはほ 同様の傾向を示すが，二の場合 4〜13\% Cr 鋼の引張り 強さは接近して大きな差が認められず，いずれも焼戻温 度 $500^{\circ} \mathrm{C}$ までは高い引張り強さを有する。一方 $0 \cdot 0.0 \%$ 


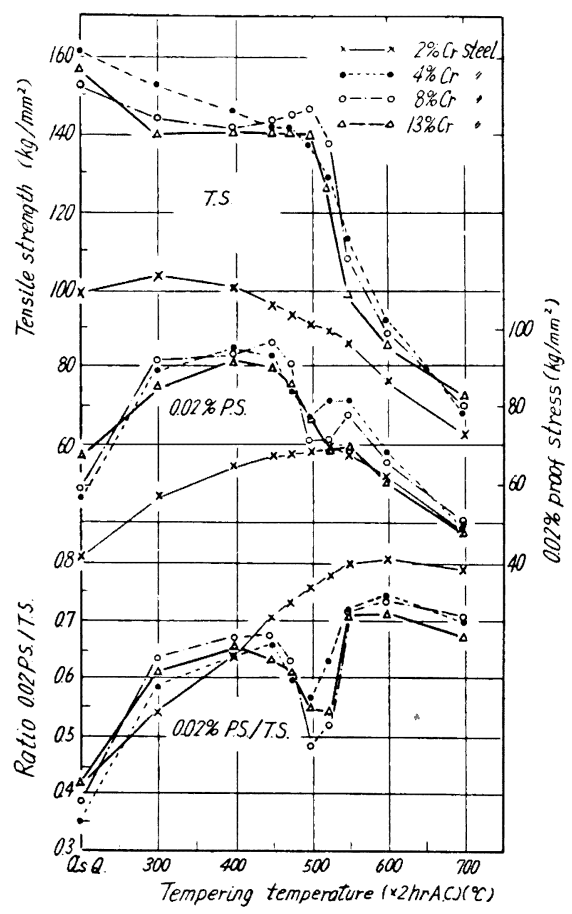

Fig. 4. Tensile property of various $\mathrm{Cr}$-steels Hardening: $2 \sim 00_{0}^{\circ} \mathrm{Cr}$ steel $-900^{\circ} \mathrm{C} \times$ $1 \mathrm{hr}$ O. Q., $150.0 \mathrm{Cr}$ steel $-1000^{\circ} \mathrm{C} \times$ 1 h O. Q.

耐力の変化をるると，40。Cr 以上の $\mathrm{Cr}$ 鋼については約 $500 \mathrm{C}$ 附近において低下の現象が和机たが，2\% Cr 鋼 ひはこのような特異な現象は観察されない。したがつて 降伏比は図に示すように，4\% Cr 以上のものに括いて異 常低下の現象が明瞭に示された。

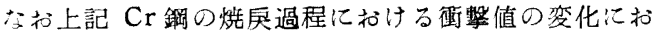
いて, 4〜 $13 \% \mathrm{Cr}$ 鎆では焼戻温度 $500 \sim 550^{\circ} \mathrm{C}$ 亿おいて 衝撃值の著しい低下がみられたが，2\% Cr 鋼ではそれが 観察されなかつた。

\section{IV. 結}

\section{需}

Cr鋼の焼戻過程に打ける引張性質の変化を陚験した 結果，4〜13\% Cr 鎆の500 C の焼戻しに拓いて降伏比 の異常低下が観察されたが，この現象に関してつぎのよ うな事実が明らかにされた。

(1) 焼戾軟化されやすい低 $\mathrm{Cr}$ 鋼こは降伏比の異常 低下は打こらない。

（2） $13 \% \mathrm{Cr}$ 鐦について，烧入温度が低い場合には 降伏比の異常低下の度合は著しい。な枚入加熱保持時 間とは特に大きな関係をもたない。

（3）烧杘保持時間を長くすると，降状比の異常低下 はより低温度側で打こる。

（4）降伏比の異常低下の現象は第 2 次硬化を示す焼 戻温度領域で扣こり, 第 2 次硬化現象と関連する。

（5）降伏比の異常低下の現象は, 焼戻冷却速度なら び河䧕験に打ける歪速度と特に関係はない。

\section{交}

献

1) K.J. Irvine et al.: J. Iron \& Steel Inst. (U. K.), 195 (1960) 8, P. 386

(170)

\section{軸受鋼のセメンタイト粒度と転 動疲労 tro.643\$2}

不二越鎙材

○大沢 真澄・工博 近藤 正男

Cementite Grain Size and Rolling Fatigue of Bearing Steel.

Masumi Ohsawa and Dr. Masao Kondo.

\section{I. 緒}

言PF, $030 \sim 2032$

コロガリ軸受の耐久寿命に影響する因子は，設計，工 作，潤滑，取付なとの機械的因子と熱処理を含さ材質的 因子に大別される。後者は根本的にはマルテンサイト基 地の強さであり, 先天的なものとしては鋼中非金属介在 物の量と質が有力因子であるので，真空溶解法などによ つて，これが絶対量の低減を計り，また，新しい溶解技 術の開発は介在物の内容を変化せしめて, 耐久寿命の向 上に寄与しているが，後天的なものこしてセメンタイト 粒度の影響を挙げるととができよう。

彷来，国産の軸受鋼は一般に過狫鈍気味でメンタイ 卜粒が粗大であるといわれてきた。これが微細なものは 粗大なものに比して, 機㭜的強度が勝り, 材料の疲労剥 離による耐久寿命に対しても，微細組織が望ましいこと は明かであるが，反面，JISによる焼鈍力夕サの制約や 切削能率向上の立場からは相反する要請がなされ，実状 は焼鈍設備とも関連があつて, 必ずしも微紐ではない。

\section{II. 実験方法と結果の概要}

耐久寿命に対するセメンタイト粒度の影響を調べる目 的から，焼鈍条件を変えて七メンタイト粒度の異なる素 材を調製し，烧入机焼戻したリング状試片で転動疲労試 験を行なつた（Table 1，Fig. 1). 軸受のカタサは寿 命に影響することが明かであるのご，㷣入れ狫戻し後，
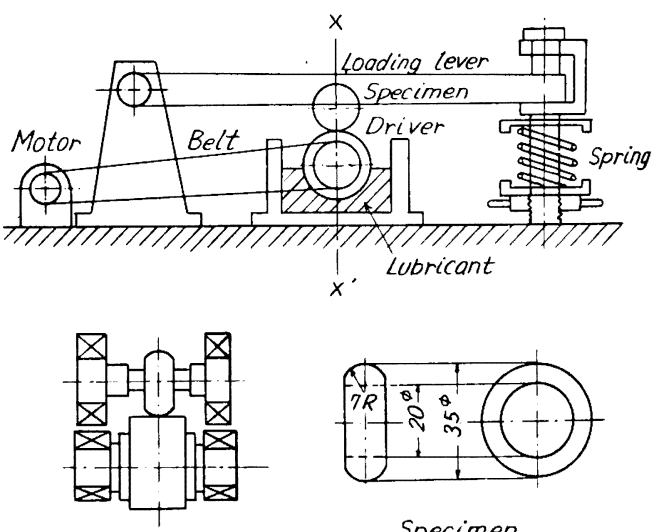

Specimen

$x-x^{\prime}$ section

Fig. 1. Driver-follower type rolling fatigue tester. 
Table 1. Heat-treating conditions and fatigue lives of specimens.

\begin{tabular}{|c|c|c|c|c|c|c|c|c|}
\hline $\begin{array}{l}\text { Group } \\
\text { No. }\end{array}$ & Annealing conditions & 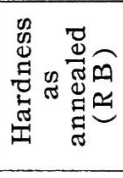 & 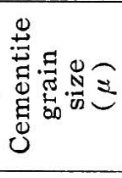 & 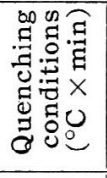 & 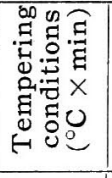 & 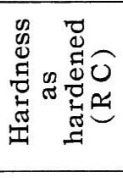 & 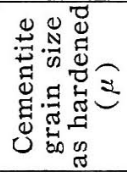 & 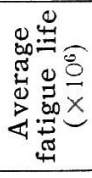 \\
\hline 1 & $\begin{array}{l}\left(760^{\circ} \mathrm{C} \times 1 \mathrm{hr} \rightarrow 700^{\circ} \mathrm{C} \times 1 \mathrm{hr}\right) \\
\times 3 \rightarrow \text { Water cooled }\end{array}$ & $97 \cdot 5$ & $0 \cdot 895$ & $815 \times 20$ & $160 \times 60$ & 62 & $0 \cdot 960$ & $30 \cdot 64$ \\
\hline 2 & $\begin{array}{l}810^{\circ} \mathrm{C} \times 0 \cdot 5 \mathrm{hr} \rightarrow 740^{\circ} \mathrm{C} \times 3 \mathrm{hr} \\
\rightarrow \text { Water cooled }\end{array}$ & $96 \cdot 2$ & $0 \cdot 944$ & $820 \times 20$ & " & " & $0 \cdot 988$ & $24 \cdot 24$ \\
\hline 3 & $\begin{array}{l}770^{\circ} \mathrm{C} \times 3 \mathrm{hr} \rightarrow 800^{\circ} \mathrm{C} \times 16 \mathrm{hr} \\
10^{\circ} \mathrm{C} / \mathrm{hr} \\
\stackrel{2}{\longrightarrow} 720^{\circ} \mathrm{C} \rightarrow \text { furnace }\end{array}$ & $89 \cdot 6$ & $1 \cdot 157$ & $840 \times 20$ & " & " & $1 \cdot 219$ & $10 \cdot 14$ \\
\hline 4 & $\begin{array}{l}\text { cooled } \\
770^{\circ} \mathrm{C} \times 3 \mathrm{hr} \rightarrow 790^{\circ} \mathrm{C} \times 45 \mathrm{hr}\end{array}$ & & & & & & & \\
\hline & $\underset{\text { cooled }}{\stackrel{10 \mathrm{C} / \mathrm{hr}}{\longrightarrow}} 720^{\circ} \mathrm{C} \rightarrow$ furnace & $86 \cdot 2$ & $1 \cdot 212$ & $860 \times 20$ & " & " & $1 \cdot 528$ & $5 \cdot 28$ \\
\hline 5 & $\begin{array}{l}\text { No. } 3 \rightarrow 810^{\circ} \mathrm{C} \times 0.5 \mathrm{hr} \rightarrow \\
770^{\circ} \mathrm{C} \times 6 \mathrm{hr} \rightarrow \text { furnace } \\
\text { cooled }\end{array}$ & $84 \cdot 7$ & $1 \cdot 365$ & $870 \times 20$ & " & " & $1 \cdot 732$ & $1 \cdot 74$ \\
\hline
\end{tabular}

Remark: Before annealing, original steel was normalized. $\left(930^{\circ} \mathrm{C} \times 3 \mathrm{hr}\right.$ air cooled)

ほほ同一カタサを得られるように焼入れ条件（温度）を 選んだ.すなわち，素材のセメンタイト粒が粗大になる につれて,オーステナイトへ溶け込み難く, 焼入れ力夕

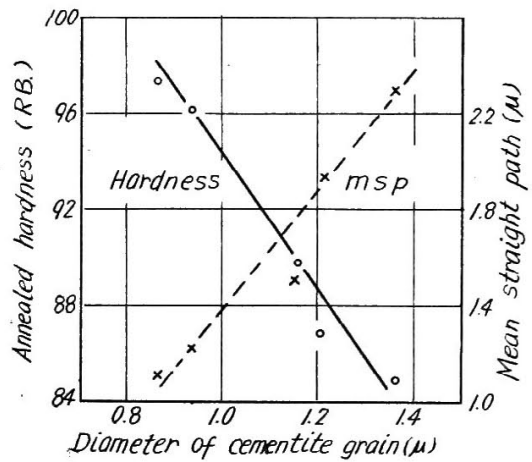

Fig. 2. Cementite grain size, mean straight path and hardness of annealed steel.

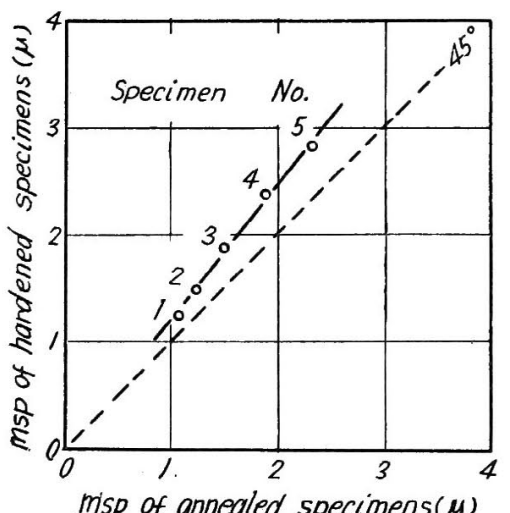

Fig. 3. Mean straight paths of annealed and hardened specimens.

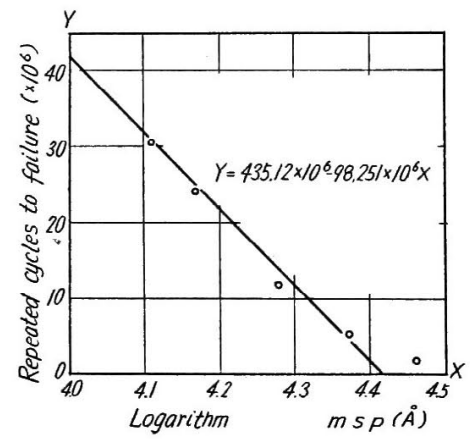

Fig. 4. Fatigue lives and logarithm mean straight paths of hardened specimens.

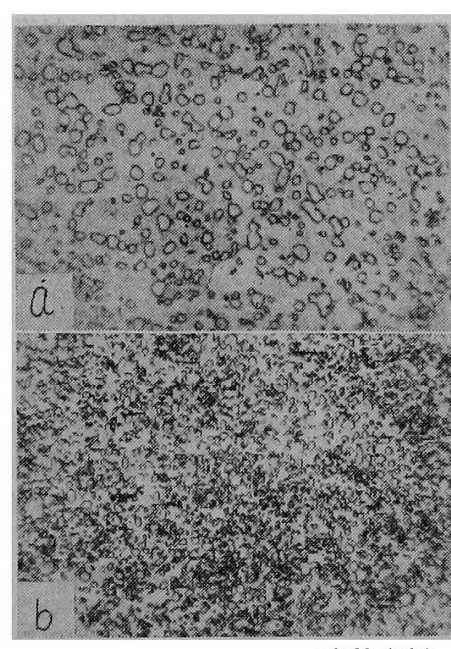

$\times 1500(3 / 5)$

a): Group No. 5, b): Group No. 2

Photo. 1. Typical annealed structures.
サがでないので， 焼入れ温度か保持 時間を変えなけれ ばならないが,こ の実験では生産性 が同一，すなわち 烧入れ加熱保持時 間を同一となし得 るような焼入れ温 度を採用した。

したがつて, セ メンタイト粒の粗 大なものに対して は慣用せられる烧 入れ温度上りやや 高くなつている。 寿命試賖の結 果, セメンタイト 粒の粗大となるに つれて，すなわち， 素材の燃鈍力タサ 
の低いはど転動面に豩畔の発生による寿命低下の傾向が 明瞭に認められる。さて，軸受鋼いようにセメンタイト 定球状化処理して使用:供する工具鋁などでは，セメン タイト粒間の平均距訪（mean straight path）の対数

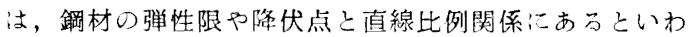
れるが，この実験の結果から：材料の疲労に基因玄る剥 離の発生，市なわち耐久寿命に対してもこの関係が成立 することが判明した。

Fig. 2 は烧鈍材のセメンりイト平均粒径し $\mathrm{msp}$ 打よ

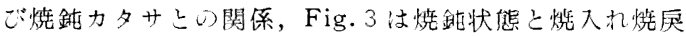
し状態の msp の関係，Fig. 4 は疲労寿命亡 mspの 対数との関係を，また，Photo. 1 は燃鈍組織の一例を 示した。(以下省略)

\section{文献}

1) C. S. Roberts: Transactions of the A.S.M., $44(1052)$, p. 1150

2) 大呮：不二越技報，18(1962) S, p. 37

\section{（171）炭素鋼の高温ねじり試験成績に およほす鋼質の影響について}

住友金属工栄，銅管製造所

井上愰. ○真壁 郁雄

On the Effect of Metallurgical Factors on the Hot Torsion Characteristics of Carbon Killed Steel. P P $2032 \sim 2034$ Akira Inoue and Ikuo MAKABE.

\section{I. 緒}

\section{言}

鋼材のいわゆる熱間ての加工性を判断する方法の1つ に高温枋しり試験がある1). 加工性を判断する規隼とし ては，所定の温度で，ある回転数でねじつたときの材料 の破断するまでの极しり数が一般に用いられている1). これは特にマンネスマン式継目なし管の製管性とよく対 芯するといわれて抢り 2)，当所においても製管キズ対策 の1つとして鍼材の日常管理項目に本方法を採用してい 万.

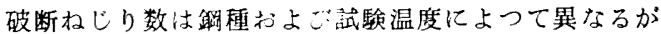
そのほかに同一チャージももこの内部の空孔，あるいは 非金属介在物の存在, 鉔造比, 加熱状沉, 試験機, 試験 片形状, 回転速度, 試験片の試験機への取り付け方法な どによつて遧つてくる゙

実際製管時には，硧種あるいは同一鋼種でも，チャー シによつて製管性が必ずしも一定していないことに着眼 して，今回上記の高温ねじり試験成績におよぼす鋼質諸 因子の影響を明らかにしようと試みた。本報は第一報と して, C含有量 $0 \cdot 0$ 〜 $14 \%$ のキルド鎆の結果を統計 的手法により解析したものである.

\section{II. 高温ねじり試験披}

1. モ一夕一容量： $5 \mathrm{P}, 3$ 相誘導式, $1800 \mathrm{rpm}$

2. 試験機本体

（1）型式：軸水平式，無張力一端固定一端回転駆動 式.

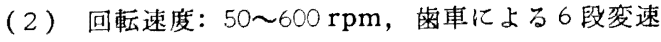
式
（3）权じり数検出装罪：クラッチ離脱用マグネット

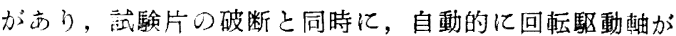
停止する。この駆動軸にある仙心りングによる電気開閉 で，ねじり数さデカトロンないしはペン書きオシロに記 録する。

\section{III. 調 査因子}

破断ねしり数に影碞を打よぽす鋼質の因子として，化 学成分 $(\mathrm{C}, \mathrm{Si}, \mathrm{Mn})$, 不純物 $(\mathrm{P}, \mathrm{S}, \mathrm{Cu}, \mathrm{As}, \mathrm{Sn}$, Sol-Al), Mn/S, ガス拈 (total $\mathrm{O}, \mathrm{N}$ ), サンド(total, $\mathrm{SiO}_{2}, \mathrm{Al}_{2} \mathrm{O}_{3}$ )，ミク口清浄度 ( $\mathrm{A}$ 型, $\mathrm{A}+\mathrm{B}+\mathrm{C}$ 型) 招 よで地キズ総長さなどについて調查した。

\section{IV. 供試材および調查方法}

1. 供試試料

(1) 対象鋼種衫よび調查数

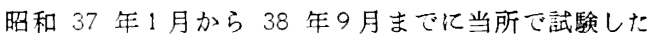
平炉製，電気炉製およざ転炉製の 7 鋼種の炭素キルド銅 134 チャーシ 164 本である.

（2）供誈試料採取要領

こ〜の $\mathrm{t}$ 鋼塊を120〜200 $\mathrm{mm} \oint$ 亿圧延した丸鋼の主と して中心部 $500 \mathrm{~mm}$ の横断面から分析試料を，釷造した

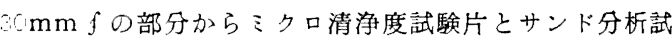
料を,さらに造した $20 \mathrm{~mm} \oint$ の部分から高温㸚じり 試験片を，15 mm $\oint$ の部分加ら酸素分析試料を採取し た。

（3）高温站しり試験片寸法および試験条件

A. 寸法：平行部门長さ $50 \mathrm{~mm}$, 直径 $10 \mathrm{~mm} \oint$, 隅 肉半径 $5 \mathrm{~mm}$ つかみ部直径 $20 \mathrm{~mm} \oint$ 打よび試験片長さ $180 \mathrm{~mm}$.

B. 試験温度：エレマ炬を用いて，空気䨌团気中て， $1100 \mathrm{C}$ およ゙゙ $1200 \mathrm{C}$ 亿 $25 \mathrm{~min}$ 間保持後試験した。

C. 試験回転速度：300 $\mathrm{rpm}$.

(4) 整理方法

これぞ机の鋼質因子と高温权じり成績との関係を散布 図に書き，相関分析を行なつた。Fig. 1〜3には一例と してS，O およびNの関係を示している。

\section{V. 結果とその考察}

各成分の含有籁用亡, 各散布図から求めた単相関係数

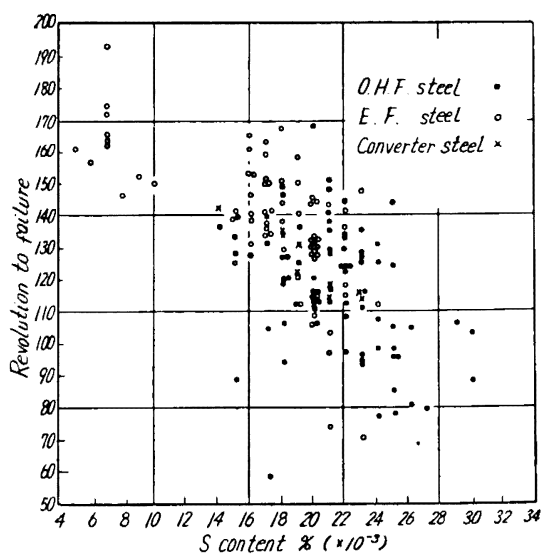

Fig. 1. The relation of $\mathrm{S}$ content to revolution to failure. (Testing temperature at $1200^{\circ} \mathrm{C}$ ) 
Table 1. The correlation coefficient of each metallurgical factor.

\begin{tabular}{|c|c|c|c|c|c|c|c|}
\hline & $\begin{array}{l}\text { Steel } \\
\text { factor }\end{array}$ & $\begin{array}{l}\text { Range of } \\
\text { content }\end{array}$ & $\begin{array}{l}\text { Testing } \\
\text { temp. }{ }^{\circ} \mathrm{C}\end{array}$ & $\begin{array}{l}\text { Degree of } \\
\text { freedom }\end{array}$ & $\begin{array}{c}\text { Correlation } \\
\text { coefficient }\end{array}$ & $\begin{array}{l}\text { Distribu- } \\
\text { tion of } t\end{array}$ & $\underset{\text { level }}{\text { Significant }}$ \\
\hline \multirow{4}{*}{$\begin{array}{l}\text { Chemical } \\
\text { component }\end{array}$} & $\mathrm{C}$ & $0.08 \sim 0.44 \%$ & $\begin{array}{l}1100 \\
1200\end{array}$ & 161 & & & \\
\hline & $\mathrm{Si}$ & $0.08 \sim 0.35 \%$ & $\begin{array}{l}1100 \\
1200\end{array}$ & 161 & & & \\
\hline & $\mathrm{Mn}$ & $0.36 \sim 0 \cdot 87 \%$ & $\begin{array}{l}1100 \\
1200\end{array}$ & 161 & & & \\
\hline & $\mathrm{Mn} / \mathrm{S}$ & $15 \sim 97$ & $\begin{array}{l}1100 \\
1200\end{array}$ & 160 & & & \\
\hline \multirow{6}{*}{ Impurity } & $\mathrm{P}$ & $0 \cdot 005 \sim 0 \cdot 034 \%$ & $\begin{array}{l}1100 \\
1200\end{array}$ & $\begin{array}{l}161 \\
160\end{array}$ & -0.078 & 0.05 & \\
\hline & $\mathrm{S}$ & $0.005 \sim 0.030 \%$ & $\begin{array}{l}1100 \\
1200\end{array}$ & $\begin{array}{l}161 \\
160\end{array}$ & $\begin{array}{l}-0.574 \\
-0.585\end{array}$ & $\begin{array}{l}0 \cdot 02 \\
9 \cdot 07\end{array}$ & $\begin{array}{l}>t 0 \cdot 001 \\
>t 0 \cdot 001\end{array}$ \\
\hline & $\mathrm{Cu}$ & $0.05 \sim 0 \cdot 10^{\circ}$ & $\begin{array}{l}1100 \\
1200 \\
\end{array}$ & 146 & & \\
\hline & As & $0.010 \sim 0.050 \%$ & $\begin{array}{l}1100 \\
1200 \\
\end{array}$ & 152 & & & \\
\hline & $\mathrm{Sn}$ & $0.007 \sim 0.042 \%$ & $\begin{array}{l}1100 \\
1200 \\
\end{array}$ & 158 & & & \\
\hline & Sol-A1 & $0.001 \sim 0.0300^{\circ}$ & $\begin{array}{l}1100 \\
1200\end{array}$ & $\begin{array}{l}157 \\
155\end{array}$ & $\begin{array}{l}0.010 \\
0.046\end{array}$ & $\begin{array}{l}0.125 \\
0.597\end{array}$ & \\
\hline \multirow{2}{*}{$\begin{array}{l}\text { Gas } \\
\text { component }\end{array}$} & $\mathrm{O}_{2}$ & $0.0028 \sim 0.0174 \%$ & $\begin{array}{l}1100 \\
1200\end{array}$ & $\begin{array}{l}164 \\
163\end{array}$ & $\begin{array}{l}-0 \cdot 304 \\
-0 \cdot 159\end{array}$ & $\begin{array}{l}4 \cdot 06 \\
2 \cdot 04\end{array}$ & $\begin{array}{l}>t 0.001 \\
>t 0.05\end{array}$ \\
\hline & $\mathrm{N}_{2}$ & $0.0031 \sim 0.010 \%$ & $\begin{array}{l}1100 \\
1200\end{array}$ & $\begin{array}{l}157 \\
156\end{array}$ & $\begin{array}{l}0.554 \\
0.513\end{array}$ & $\begin{array}{l}7 \cdot 01 \\
6 \cdot 45\end{array}$ & $\begin{array}{l}<t 0.001 \\
<t 0.001\end{array}$ \\
\hline \multirow{3}{*}{ Sand } & Total & $0.0012 \sim 0.0173 \%$ & $\begin{array}{l}1100 \\
1200\end{array}$ & $\begin{array}{l}160 \\
159\end{array}$ & $\begin{array}{l}-0.136 \\
-0.081\end{array}$ & $\begin{array}{l}1 \cdot 73 \\
1 \cdot 02\end{array}$ & $>t 0 \cdot 1$ \\
\hline & $\mathrm{SiO}_{2}$ & $0.0001 \sim 0.0160 \%$ & $\begin{array}{l}1100 \\
1200\end{array}$ & $\begin{array}{l}162 \\
162\end{array}$ & $\begin{array}{l}-0 \cdot 334 \\
-0 \cdot 244\end{array}$ & $\begin{array}{l}4 \cdot 48 \\
3 \cdot 18\end{array}$ & $\begin{array}{l}>t 0 \cdot 001 \\
>t 0 \cdot 01\end{array}$ \\
\hline & $\mathrm{Al}_{2} \mathrm{O}_{3}$ & $0.0002 \sim 0.0069 \%$ & $\begin{array}{l}1100 \\
1200\end{array}$ & $\begin{array}{l}163 \\
162\end{array}$ & $\begin{array}{l}0.076 \\
0.083\end{array}$ & $\begin{array}{l}0.967 \\
1.06\end{array}$ & \\
\hline \multirow{2}{*}{$\begin{array}{l}\text { Non-metalic } \\
\text { inclusion }\end{array}$} & $A+B+C$ & $0.017 \sim 0.367 \%$ & $\begin{array}{l}1100 \\
1200\end{array}$ & $\begin{array}{l}163 \\
163\end{array}$ & $\begin{array}{l}-0.407 \\
-0.373\end{array}$ & $\begin{array}{l}5 \cdot 65 \\
4 \cdot 83\end{array}$ & $\begin{array}{l}<t 0 \cdot 001 \\
<t 0 \cdot 001\end{array}$ \\
\hline & $\mathrm{A}$ & $0.002 \sim 0.350 \%$ & $\begin{array}{l}1100 \\
1200\end{array}$ & $\begin{array}{l}163 \\
163\end{array}$ & $\begin{array}{l}-0 \cdot 443 \\
-0 \cdot 399\end{array}$ & $\begin{array}{l}6 \cdot 27 \\
5 \cdot 52\end{array}$ & $\begin{array}{l}<t 0 \cdot 001 \\
<t 0 \cdot 001\end{array}$ \\
\hline Sand mark & $\begin{array}{r}\text { Total } \\
\text { length }\end{array}$ & $0 \cdot 1 \sim 210 \mathrm{~mm}$ & $\begin{array}{l}1100 \\
1200 \\
\end{array}$ & 159 & & & \\
\hline
\end{tabular}

と $\mathrm{t}$ 検定結果を Table 1 亿示す. この結果

1. 含有 $\mathrm{S}$ 量は $1100^{\circ} \mathrm{C}$ 扣よび $1200^{\circ} \mathrm{C}$ と高温㸚し り成續と強い負の相関を示す。これは熱間加工性を著し く悪化させるもので，Sによる赤熱ぜい性のためであ り，結晶粒間にもろい硫化物が存在するためと考えられ る4). これは硫化物を主体とするA型非金属介在物の存 在が高温ねしり成樍に対し，強い負の相関を示している ととともよく対応している。

2. 含有 $\mathrm{O}$ 量と, 試験温度によつて多少違いがある が，高温ねじり成績に対し強い負の相関を示している. 今回調查した範囲の○含有量ではほとんど大部分は化合 物として存在しており，したかつて酸化物が高温ねしり 成績に悪影響を与えているものと思われる。てははサン ド量 $\mathrm{Al}_{2} \mathrm{O}_{3}$ についてははつきりしなかつたが， $\mathrm{SiO}_{2}$ に
ついてはＯ含有量と同ように負の相關を示していること とも対応するものと思われ，Si に上る脱酸の影響が大 きいことを示唆している。

3. $\mathrm{N}$ 量は高温枚じり成樍に対し, きわめて強い正相 関を示しており，熱間加工性を向上させるように思われ る.これは散布図をほぼ 2 分したところの平炉製と電気 炉製について別々に調査した結果でも，てれごれに強い 正の相関がみられる.すなわち相関係数は平炉製 0.409 ( $0.1 \%$ 有意) また電気炻製は $0.470(0.1 \%$ 有意）で ある: 今回調查を行なつた範囲の N含有量では $1100^{\circ} \mathrm{C}$ 〜 $1200^{\circ} \mathrm{C}$ での Nの固体の溶解度 $0.023 \%$ ～ $0.0215 \%$ 上 り低いので含有 $\mathrm{N}$ 量は固溶体として存在し，したがつて 固溶体の $\mathrm{N}$ が熱間加工性を向上させるものと考えられ る。 


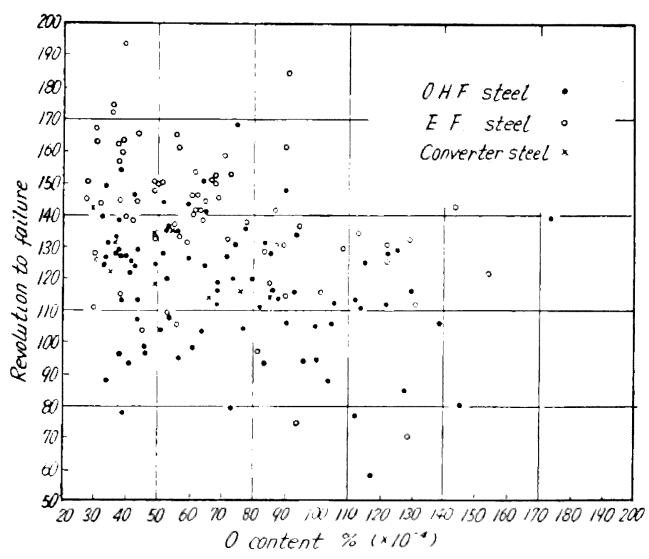

Fig. 2. The relation of $\mathrm{O}$ content to revolution to failure. (Testing temperature at $\left.1100^{\circ} \mathrm{C}\right)$

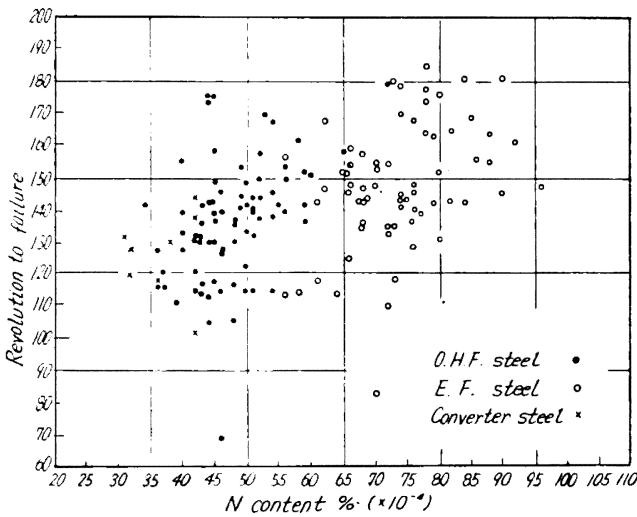

Fig. 3. The relation of $\mathrm{N}$ content to revolution to failure. (Testing temperature at $1200^{\circ} \mathrm{C}$ )

な怙このような統計結果のみからはこれ以上の考察 は困難之思われ，含有 $\mathrm{N}$ 量の影響については $\mathrm{N}$ 量をいろ いろと変妾た材料を製造し，てれについて調查を行なつ ていら.

4. 含有 $\mathrm{P}, \mathrm{Cu}, \mathrm{As}$ 打よび $\mathrm{Sn}$ 量あるいは $\mathrm{C}, \mathrm{Si}$, $\mathrm{Mn}, \mathrm{Mn} / \mathrm{S}$, Sol.-Al， $\mathrm{Al}_{2} \mathrm{O}_{3}$ 打よび地キズなどについ ては, 今回の調査の含有量範团では破断ねしりり数との相 関は認められなかつた。しかしこれは必ずしも熱間加工 性に対して影響を与えないということではない677) と考 えられ，今後検討をはかりたいと考える。

$$
\text { VI. 結 言 }
$$

熱間加工性に影暨を与えると思われる種々の治金的因 子について高温ねじり試跧成緹をもとに，キルド炭素鎆 について統計的に調查を行なつた。その結果明らかにな つたことは

1. $\mathrm{S}, \mathrm{O}$, サンド量 $\mathrm{SiO}_{2}$, ミクロ清浄度(特にA 型) などは高温ねじり成績に対し強い負の相関を示した。こ れらの因子は熱間加工性を少下させるものと思われる。

2. $\mathrm{N}$ は高温ねしり成績に対し强い正の相関を示し た. 固溶 $\mathrm{N}$ は熱間加工性を向上させるものと考えられ
る。

文献

1）森島：鉄と鋼， 44 (1958) 5, p. 552

2) 森島：鉄々銅， 44 (1958) 6, p. 660

3) 圧延理論分科会資料

4 ) A. Niedenthal: Arch. Eisenhüttenw., 79, 3, 1929

5 ）盛，他：日本学術振興会製鋼第 19 委員会資料, No. 6682

6) 中島:「鋼材表面の脆性に関する研究」(1960)

7) F. NeHL: Stahl u. Eisen, 58 (1958), 779

\section{（172）'高炭素鋼線材の組織と伸線加工性} 八幡製鉄，光製鉄所

岡本一生・江口直記・O富永治朗

Relation between the Structures and Cold Drawabilities of High Carbon Commercial Steel Rods. 10,64334 Kazuo Oкамото, Naoki Eguchi and Jiro Tominaga.

I. 緒 言 PP $2034 \simeq 203 T$

高炭素鋼線材の伸線にあたつては，パテンティングし て組織を調整して打くのが普通であり，ての場合目的に 応じ種々の熱処理が施されるが, 組織と伸線加工性の関 係については必ずしも明瞭でない.

西岡はカッピー破断と組織の関係を調べているが1)2), 本報告は数種の実用鎆を用い, 特にセメンタイトの分布 様式, 機械的性質と伸線加工性の關係について研究した 結果である。

\section{II. 実験試料および実験方法}

炭素含有量がこれぞれ $0.75 \% ， 0.65 \% ， 0.40 \%$ ， $0.25 \%$ の $5.5 \mathrm{~mm} \oint$ の炭素鋼線材を Table 1 に示す 熱処理によりパーライト, ソルバイト,焼戻ソルバイト, 球状パーライトにした。

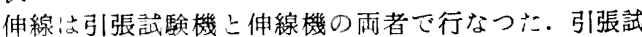
験機による場合は, 同辺の脱炭などの影響除去のため,片 面 $0.3 \mathrm{~mm}$ 研削して $4.0 \mathrm{~mm} \oint$ 亿仕上げ, コーシン $\mathrm{M}$

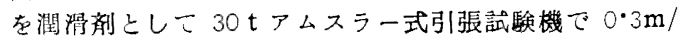
$\min$ の速度で 1 ダイス当り約 $23 \%$ の減面率こ 0.05 $\mathrm{mm} \oint$ まこ伸線した。伸線機伸線の場合は，普通作業 通り酸洗, 石灰清け後コーシン $\mathrm{M}$ 用い, 昭和機機制 ンスリップ横型試験機二連で $150 \mathrm{~m} / \mathrm{min} の$ 速度で 0.95 $\mathrm{mm} \oint$ まこ伸線した。

断線の発生をチェックするとともに，伸線途中で試料 を採取し，引張試験扣よび電子影微鏡観察を行なつた。

\section{1. 各種鋼の伸楾限界}

\section{III. 実 験 結 果}

Table 1 亿各実䮖試料に拖した熱処理条件と機珹的性 質を示し，伸線速度を変えた場合の伸線限界サイズを示 す.これょり C\%が低いはど，また伸線速度がさい ほど細線まで断線は生じ難いことは明瞭である。また同 一鋼程でも伸線前の組織が変わるととにより伸線限界は 著しく異なり，鉛掞よび空気パテンティンダ材は球状化 